\title{
Pathways and key intermediates required for obligate aerobic ammonia-dependent chemolithotrophy in bacteria and Thaumarchaeota
}

\author{
Jessica A Kozlowski ${ }^{1}$, Michaela Stieglmeier ${ }^{2,3}$, Christa Schleper ${ }^{2}$, Martin G Klotz ${ }^{4,5}$ and \\ Lisa Y Stein ${ }^{1}$ \\ ${ }^{1}$ Department of Biological Sciences, University of Alberta, Edmonton, Alberta, Canada; ${ }^{2}$ Department of \\ Ecogenomics and Systems Biology, Division Archaea Biology and Ecogenomics, University of Vienna, Wien, \\ Austria; ${ }^{3}$ Department of Biology I, Ludwig-Maximilians-University of Munich, Biocenter, Planegg-Martinsried, \\ Germany; ${ }^{4}$ Department of Biology, Queens College, The City University of New York, Flushing, NY, USA and \\ ${ }^{5}$ Institute of Marine Microbes \& Ecospheres and State Key Laboratory of Marine Environmental Science, \\ Xiamen University, Xiamen, China
}

\begin{abstract}
Chemolithotrophic ammonia-oxidizing bacteria and Thaumarchaeota are central players in the global nitrogen cycle. Obligate ammonia chemolithotrophy has been characterized for bacteria; however, large gaps remain in the Thaumarchaeotal pathway. Using batch growth experiments and instantaneous microrespirometry measurements of resting biomass, we show that the terrestrial Thaumarchaeon Nitrososphaera viennensis EN76 ${ }^{\top}$ exhibits tight control over production and consumption of nitric oxide (NO) during ammonia catabolism, unlike the ammonia-oxidizing bacterium Nitrosospira multiformis ATCC $25196^{\top}$. In particular, pulses of hydroxylamine into a microelectrode chamber as the sole substrate for $N$. viennensis resulted in iterative production and consumption of NO followed by conversion of hydroxylamine to nitrite. In support of these observations, oxidation of ammonia in growing cultures of $\mathbf{N}$. viennensis, but not of $\mathbf{N}$. multiformis, was inhibited by the NO-scavenger PTIO. When based on the marginal nitrous oxide $\left(\mathrm{N}_{2} \mathrm{O}\right)$ levels detected in cell-free media controls, the higher levels produced by $\mathbf{N}$. multiformis were explained by enzyme activity, whereas $\mathrm{N}_{2} \mathrm{O}$ in $\mathrm{N}$. viennensis cultures was attributed to abiotic reactions of released $\mathrm{N}$-oxide intermediates with media components. Our results are conceptualized in a pathway for ammonia-dependent chemolithotrophy in Thaumarchaea, which identifies NO as an essential intermediate in the pathway and implements known biochemistry to be executed by a proposed but still elusive copper enzyme. Taken together, this work identifies differences in ammonia-dependent chemolithotrophy between bacteria and the Thaumarchaeota, advances a central catabolic role of NO only in the Thaumarchaeotal pathway and reveals stark differences in how the two microbial cohorts contribute to $\mathrm{N}_{2} \mathrm{O}$ emissions.
\end{abstract}

The ISME Journal (2016) 10, 1836-1845; doi:10.1038/ismej.2016.2; published online 16 February 2016

\section{Introduction}

Ammonia-oxidizing archaea, in the phylum Thaumarchaeota, and ammonia-oxidizing bacteria are abundant and diverse microorganisms that control the oxidation of ammonia $\left(\mathrm{NH}_{3}\right)$ to nitrite $\left(\mathrm{NO}_{2}^{-}\right)$in the global biogeochemical nitrogen cycle. Through many decades of research, the biochemical pathway for chemolithotrophic growth of ammonia-oxidizing bacteria has been principally elucidated (SayavedraSoto and Arp, 2011); however, this pathway has yet

Correspondence: LY Stein, Department of Biological Sciences, University of Alberta, CW 405 Biological Sciences Building, Edmonton, Alberta T6G2E9, Canada.

E-mail: lisa.stein@ualberta.ca

Received 17 April 2015; revised 14 December 2015; accepted 24 December 2015; published online 16 February 2016 to be characterized in the more recently discovered thaumarchaeotal ammonia-oxidizers. This lesser understanding is largely due to the difficulty of growing reliable and sufficient biomass from pure cultures for performing physiological experiments, thus making identification of the genetic inventory that supports chemolithotrophic growth of the thaumarchaeotal ammonia-oxidizers a challenge. In contrast, the pathways for the autotrophic assimilation of carbon have been identified in both cohorts (Arp et al., 2007; Könneke et al., 2014).

Previous experiments with the marine isolate Nitrosopumilus maritimus SCM1 indicated that ammonia oxidation is dependent on the activity of the ammonia monooxygenase enzyme and (an) unknown enzyme(s) that convert(s) hydroxylamine $\left(\mathrm{NH}_{2} \mathrm{OH}\right)$ to $\mathrm{NO}_{2}^{-}$and provide electrons for energy 
conservation (Vajrala et al., 2012). In ammoniaoxidizing bacteria, this second step is performed by hydroxylamine dehydrogenase (EC 1.7.2.6); however, no homologues of hydroxylamine dehydrogenaseencoding genes have been identified in genome sequences obtained from any pure or enrichment culture of Thaumarchaea (Walker et al., 2010; Kim et al., 2011; Tourna et al., 2011; Spang et al., 2012). In addition to $\mathrm{NH}_{2} \mathrm{OH}$, there is also evidence that nitric oxide (NO) plays an important role in the Thaumarchaeotal but not in the bacterial ammonia oxidation pathway (Shen et al., 2013; Martens-Habbena et al., 2015). Martens-Habbena et al. (2015) demonstrated that NO accumulated in $N$. maritimus SCM1 cultures during active oxidation of $\mathrm{NH}_{4} \mathrm{Cl}$ in a closed microrespirometry chamber, and was released at higher levels under saturating versus non-saturating availability of $\mathrm{NH}_{4} \mathrm{Cl}$. Exposure to increasing concentrations of an NO-scavenging compound over a $24 \mathrm{~h}$ period resulted in decreased levels of nitrite production in batch cultures of ammonia-oxidizing Thaumarchaea, but not bacteria (Martens-Habbena et al., 2015). The authors concluded that NO was either released as a free intermediate during ammonia oxidation by $N$. maritimus, or it could serve a functional role as an electron delivery mechanism to ammonia monooxygenase, an idea that has been proposed previously (Schleper and Nicol, 2010).

Although the detection of nitrous oxide $\left(\mathrm{N}_{2} \mathrm{O}\right)$ has been reported for both enrichments and pure cultures of Thaumarchaea engaged in ammonia oxidation (Santoro et al., 2011; Loscher et al., 2012; Jung et al., 2014; Stieglmeier et al., 2014b), the isotope data reported by Stieglmeier et al. (2014b) revealed that ammonia-oxidizing Thaumarchaea cannot enzymatically reduce $\mathrm{NO}_{2}^{-}$to $\mathrm{N}_{2} \mathrm{O}$ via $\mathrm{NO}$ in the pathway known as 'nitrifier denitrification'. Several publications have suggested that ammoniaoxidizing Thaumarchaea are a major source of $\mathrm{N}_{2} \mathrm{O}$ to the environment based on their relative abundance in oxic environments, the isotopic signature of the detected $\mathrm{N}_{2} \mathrm{O}$, and that the authors failed to detect known bacterial denitrification genes and pertinent activities (Santoro et al., 2011; Loscher et al., 2012; Jung et al., 2014). Yet, control experiments to verify or falsify chemical formation of $\mathrm{N}_{2} \mathrm{O}$ facilitated by interaction of Thaumarchaeotal metabolites with components of the cultivation or incubation media or assay solutions remain absent from the literature. It should be noted that interactions of ammonia oxidation intermediates with iron, manganese, and organic compounds could generate substantial amounts of $\mathrm{N}_{2} \mathrm{O}$ under environmentally relevant conditions (Zhu-Barker et al., 2015).

The present study addresses critical ecophysiological questions about how two different cohorts of microorganisms, simultaneously involved in the biogeochemical nitrogen cycle through ammoniaoxidation, vary in their contributions, particularly to production of nitrous oxide. This study also furthers the observation of $\mathrm{NO}$ as an intermediate for ammonia chemolithotrophy in the terrestrial Thaumarchaeon Nitrososphaera viennensis strain EN76 $^{\mathrm{T}}$ (Stieglmeier et al., 2014a) by examining its complete profile of NO production and consumption during substrate oxidation at oxic conditions and the transition into an extended period of anoxia. In contrast to the above referenced studies of ' $\mathrm{N}_{2} \mathrm{O}$ production' by ammonia-oxidizing Thaumarchaea, our results do not support any scenario in which $N$. viennensis enzymatically reduces NO to $\mathrm{N}_{2} \mathrm{O}$ through a denitrification pathway. Instead, the results support that $\mathrm{N}_{2} \mathrm{O}$ was formed abiotically from NO by interaction with media components or with debris in killed cell controls. We further demonstrated that NO is an active and necessary intermediate during the oxidation of $\mathrm{NH}_{2} \mathrm{OH}$ to $\mathrm{NO}_{2}^{-}$in ammonia-oxidizing Thaumarchaea rather than participating directly in the oxidation of $\mathrm{NH}_{3}$ to $\mathrm{NH}_{2} \mathrm{OH}$ as suggested previously (Schleper and Nicol, 2010). Based on these results, a new pathway for obligate ammonia-dependent chemolithotrophy for ammonia-oxidizing Thaumarchaea is proposed that implicates a novel copper enzyme to perform a biochemistry known to occur in ammonia-oxidizing bacteria facilitated by heme-containing cytochrome $c$.

\section{Materials and methods}

\section{Strains and cultivation}

$N$. viennensis strain EN76 ${ }^{\mathrm{T}}$ was maintained at $37^{\circ} \mathrm{C}$ in $50 \mathrm{ml}$ freshwater medium (FWM) supplemented with $2 \mathrm{mM} \mathrm{NH}_{4} \mathrm{Cl}, 0.5 \mathrm{mM}$ sodium pyruvate and $50 \mu \mathrm{g} / \mathrm{ml}$ carbenicillin and buffered with HEPES (Tourna et al., 2011; Stieglmeier et al., 2014a) and inoculated at $4 \% \mathrm{v} / \mathrm{v}$. Cultures were grown in Wheaton bottles $(150 \mathrm{ml})$ sealed with caps inlaid with grey butyl rubber stoppers. Nitrosospira multiformis ATCC $25196^{\mathrm{T}}$ was maintained at $28^{\circ} \mathrm{C}$ in $100 \mathrm{ml}$ HEPES-buffered HK medium (HKM) (Krümmel and Harms, 1982) containing $3 \mathrm{mM}$ ammonium and phenol red as $\mathrm{pH}$ indicator $(\mathrm{pH}$ of $7.5-8)$ and inoculated at $5 \% \mathrm{v} / \mathrm{v}$ into $250 \mathrm{ml}$ Wheaton bottles. The $\mathrm{pH}$ of $N$. multiformis cultures was maintained with regular additions of $10 \%$ $\mathrm{NaHCO}_{3}$.

\section{Growth experiments with NO-scavenger PTIO}

For monitoring activity in the presence of an NOscavenging compound, $N$. viennensis was cultivated in $20 \mathrm{ml} \mathrm{FWM.} \mathrm{N.} \mathrm{multiformis} \mathrm{was} \mathrm{cultivated}$ in $20 \mathrm{ml}$ phosphate-buffered mineral medium (Skinner and Walker, 1961) amended with $1 \mathrm{mM}$ $\mathrm{NH}_{4} \mathrm{Cl}$ and $\mathrm{pH}$ was adjusted regularly with $5 \%$ $\mathrm{Na}_{2} \mathrm{CO}_{3}$. In early to mid-exponential phase of growth, $150 \mu \mathrm{M}$ of 2-phenyl-4,4,5,5,-tetramethylimidazoline-1oxyl 3-oxide (PTIO; Sigma-Aldrich, Vienna, Austria), a chemical that scavenges NO (Goldstein et al., 2003) 
was injected into the cultures. Ammonium consumption and nitrite production were measured over a period of 6-8 days using standard colorimetric assays (Clesceri et al., 1998) and $\mathrm{N}_{2} \mathrm{O}$ was measured via GC (AGILENT 6890N, Vienna, Austria; injector: $120^{\circ} \mathrm{C}$, detector: $350^{\circ} \mathrm{C}$, oven: $35^{\circ} \mathrm{C}$, carrier gas: $\mathrm{N}_{2}$ ) in connection with an automatic sample-injection system (DANI HSS 86.50, Head-space-Sampler, Sprockhövel, Germany). Detailed sampling and sample preparation has been described previously (Stieglmeier et al., 2014a).

\section{Instantaneous measurement of $\mathrm{NO}$ and $\mathrm{N}_{2} \mathrm{O}$ during oxidation of ammonia}

In preparation for experiments measuring instantaneous $\mathrm{O}_{2}$ consumption and either $\mathrm{NO}$ or $\mathrm{N}_{2} \mathrm{O}$ production, $N$. viennensis was inoculated at $4 \% \mathrm{v} / \mathrm{v}$ into $2 \mathrm{l}$ of HEPES-buffered FWM and N. multiformis was inoculated at $5 \% \mathrm{v} / \mathrm{v}$ into $250 \mathrm{ml} \mathrm{HKM}$. Cells were harvested at late exponential phase $(N$. viennensis, 1-1.5 mM NO- ; N. multiformis, 2-2.5 $\mathrm{mM} \mathrm{NO}_{2}^{-}$) by filtration on Supor200 $0.2 \mu \mathrm{m}$ filters (Pall, Ann Arbor, WI, USA) and rinsed three times with substrate-free media (N. viennensis, FWM; N. multiformis, HKM). Washed cells $\left(N\right.$. viennensis, ca. $1 \times 10^{11}$ total cells; N. multiformis, ca. $1 \times 10^{10}$ total cells) were resuspended into $10 \mathrm{ml}$ of substrate-free growth medium for each strain in a $10 \mathrm{ml}$ two-port microrespiratory (MR) chamber with fitted injection lids (Unisense, Aarhus, Denmark). Cell concentrations for microrespirometry experiments were chosen on the basis of comparable oxygen consumption rates between the two strains. $\mathrm{O}_{2}$ concentration was measured using an OX-MR $500 \mu \mathrm{m}$ tip diameter MR oxygen electrode (Unisense), $\mathrm{N}_{2} \mathrm{O}$ concentration was measured using an $\mathrm{N}_{2} \mathrm{O}-500 \mathrm{~N}_{2} \mathrm{O}$ minisensor electrode with $500 \mu \mathrm{m}$ tip diameter (Unisense), and $\mathrm{NO}$ was measured using an ami-600 NO sensor with $600 \mu \mathrm{m}$ tip diameter (Innovative Instruments Inc., Tampa, FL, USA). The availability of $\mathrm{O}_{2}$ in the MR chamber, a closed system, corresponded to either $c a .207 \mu \mathrm{M} \mathrm{O}_{2}$ (FWM) or $c a$. $243 \mu \mathrm{M} \mathrm{O}_{2}$ (HKM) respectively, based on equilibrium $\mathrm{O}_{2}$ concentration at operating temperatures and medium salinities. For microrespirometry experiments involving ammonia oxidation, cells were provided $2 \mathrm{mM} \mathrm{NH}_{4} \mathrm{Cl}$. The microrespirometry chamber was maintained at $37^{\circ} \mathrm{C}$ and $28^{\circ} \mathrm{C}$ for measurements with $N$. vienennsis and N. multiformis cells, respectively, reflecting their optimal growth temperatures.

Instantaneous measurement of $\mathrm{NO}$ from $\mathrm{N}$. viennensis during oxidation of $\mathrm{NH}_{2} \mathrm{OH}$

For experiments measuring the oxidation of $\mathrm{NH}_{2} \mathrm{OH}$ (99.999\% purity, Sigma-Aldrich, St Louis, MO, USA), $N$. viennensis was provided with multiple additions of $200 \mu \mathrm{M} \mathrm{NH} \mathrm{NH}_{2} \mathrm{OH}$ (based on chamber volume) to maintain a steady rate of $\mathrm{O}_{2}$ consumption. NO production was measured until $\mathrm{O}_{2}$ was undetectable in the chamber. Samples were taken post-experiment for $\mathrm{NO}_{2}^{-}$measurements.

Instantaneous ammonia and hydroxylamine oxidation by $\mathrm{N}$. viennensis in the presence of PTIO

Microrespirometry experiments with the NOscavenger PTIO were performed with $N$. viennensis cells harvested as described above; cells were incubated with $200 \mu \mathrm{M}$ PTIO in the dark with shaking at $37^{\circ} \mathrm{C}$ for $1 \mathrm{~h}$ prior to adding the cells to a $2 \mathrm{ml} 1$-port $\mathrm{MR}$ chamber at $37^{\circ} \mathrm{C}$ for the measurement of $\mathrm{NH}_{4}^{+}$- and $\mathrm{NH}_{2} \mathrm{OH}$-dependent $\mathrm{O}_{2}$ consumption (Supplementary Figure S1). Confirmation of the NO-scavenging activity of PTIO was confirmed chemically by addition of $1 \mu \mathrm{l}$ PAPA NONOate ((Z)1-[N-(3-aminopropyl)-N-(n-propyl)amino]diazen-1ium-1,2-diolate; Cayman Chemical, Ann Arbor, MI, USA; half-life of $15 \mathrm{~min}$ at $37^{\circ} \mathrm{C}$ liberating 2 moles of NO per mole of parent compound) to FWM in the $2 \mathrm{ml} \mathrm{MR}$ chamber with the $\mathrm{NO}$ sensor at $37^{\circ} \mathrm{C}$. Once the rate of $\mathrm{NO}$ release from PAPA NONOate slowed, $200 \mu \mathrm{M}$ PTIO was added to the chamber and NO disappearance was immediately measured. After $~ 7$ min of NO-chelation by PTIO, another $1 \mu \mathrm{l}$ of PAPA NONOate was added but NO levels remained below detection levels (Supplementary Figure S2).

\section{Instantaneous measurement of $\mathrm{N}_{2} \mathrm{O}$ from media and} killed-cell controls

To measure the abiotic production of $\mathrm{N}_{2} \mathrm{O}$ from either FWM or HKM, $10 \mathrm{ml}$ of cell-free media was added to the $10 \mathrm{ml} \mathrm{MR}$ chamber. The NO-donor MAHMA NONOate (6-(2-Hydroxy-1-methyl-2-nitrosohydrazino)-N-methyl-1-hexanamine, NOC-9; Cayman Chemical) was added to the MR chamber in increasing additions of $20-100 \mu \mathrm{l}$, which is equivalent to the release of $c a .1 .1-5.5 \mu \mathrm{M} \mathrm{NO}$, or in a single addition of $100 \mu \mathrm{l}$ ( $c a .5 .5 \mu \mathrm{M}$ NO). The half-life of MAHMA NONOate at pH 7.4 is $1 \mathrm{~min}$ and $3 \mathrm{~min}$ at $37^{\circ} \mathrm{C}$ and $22-25^{\circ} \mathrm{C}$, respectively. $\mathrm{N}_{2} \mathrm{O}$ production was measured using the $\mathrm{N}_{2} \mathrm{O}$ microelectrode during the decay of $1 \mathrm{~mol}$ MAHMA NONOate into 2 moles NO in either FWM or HKM. Experiments were performed at $37^{\circ} \mathrm{C}$ and $28^{\circ} \mathrm{C}$ for FWM and HKM, respectively, after sparging to $c a$. $0-3 \% \mathrm{O}_{2}$ saturation with $\mathrm{N}_{2}$ (Praxair) as determined by $\mathrm{O}_{2}$ electrode. Chemical controls to confirm that FWM alone did not react with $\mathrm{NH}_{2} \mathrm{OH}$ to form measureable $\mathrm{NO}$ involved addition of 200, 400 and $600 \mu \mathrm{M} \mathrm{NH}_{2} \mathrm{OH}$ to sparged (ca. $0-3 \% \mathrm{O}_{2}$ ) FWM or FWM+200 $\mu \mathrm{M} \mathrm{NO}_{2}^{-}$ to reflect maximum concentration available once cells depleted MR chamber $\mathrm{O}_{2}$ (Supplementary Figures S3a and b). Control experiments with heat killed $N$. viennensis (ca. $1 \times 10^{11}$ cells) were performed in sparged $\mathrm{FWM}+\mathrm{NaNO}_{2}(200 \mu \mathrm{M})$ with measurement of $\mathrm{NO}$ and $\mathrm{N}_{2} \mathrm{O}$ upon addition of $200 \mu \mathrm{M} \mathrm{NH} \mathrm{N}_{2} \mathrm{OH}$ (Supplementary Figure S4) to determine whether $\mathrm{NH}_{2} \mathrm{OH}$ interacts with cellular debris. 


\section{Results}

Effects of the NO-scavenger PTIO on $\mathrm{N}_{2} \mathrm{O}$ levels measured in cultures of $\mathrm{N}$. viennensis and $\mathrm{N}$. multiformis

To investigate the role of $\mathrm{NO}$ in chemolithotrophic oxidation of ammonia to nitrite and generation of $\mathrm{N}_{2} \mathrm{O}$ in these two organisms, batch cultures of $N$. viennensis or $N$. multiformis were grown to mid-log phase, at which point PTIO $(150 \mu \mathrm{M})$ was added (Figure 1). Addition of PTIO resulted in the immediate saturation of $\mathrm{N}_{2} \mathrm{O}$ levels in either culture as would be expected in the absence or decreasing levels of NO intermediates. However, in cultures of $N$. viennensis, PTIO also caused an inhibition of both ammonium consumption and nitrite production (Figure 1a), whereas in cultures of N. multiformis, ammonia oxidation and nitrite production continued at the same rate as before PTIO addition (Figure 1b). These results indicated that $\mathrm{NO}$ is an essential, dynamic, intermediate in the process of ammonia oxidation to nitrite and thus ammonia-dependent chemolithotrophy for $N$. viennensis, but not for N. multiformis.

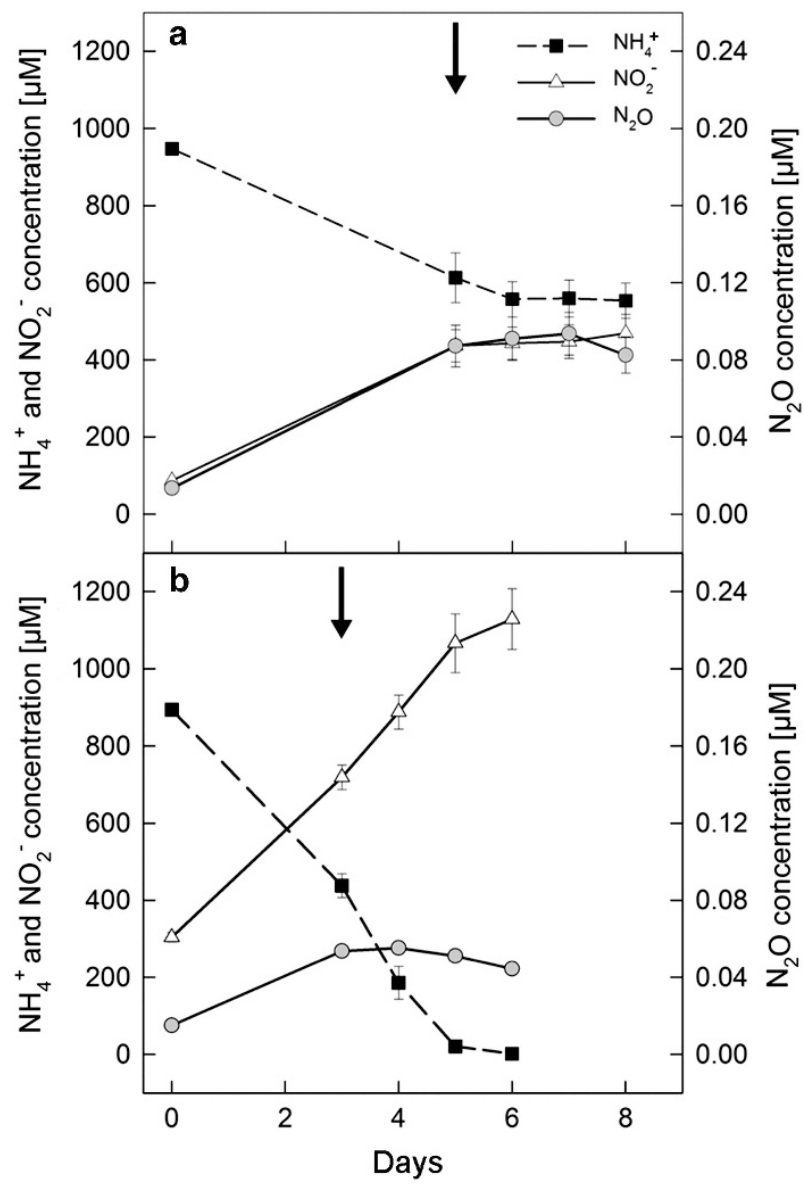

Figure 1 Inhibition of $N$. viennensis (a) and $N$. multiformis (b) with the NO-scavenger PTIO. Ammonium consumption (black squares, dotted line) and nitrite production (white triangles, solid line) as well as $\mathrm{N}_{2} \mathrm{O}$ production (gray circles, solid line) are plotted. The black arrow indicates the time point of PTIO addition $\left(150 \mu \mathrm{gml}^{-1}\right)$ to the cultures. Mean values of five-fold replicated experiments with standard deviations are shown.
Dynamics of $\mathrm{NO}$ and $\mathrm{N}_{2} \mathrm{O}$ production during and

following ammonia oxidation

The effect of PTIO on growing cultures of $N$. viennensis and $N$. multiformis indicated different requirements for NO during ammonia oxidation. Using a MR chamber, the dynamics of NO production and consumption were measured during and after ammonia oxidation ( $2 \mathrm{mM} \mathrm{NH}_{4} \mathrm{Cl}$ ) by $N$. viennensis or $N$. multiformis as determined by $\mathrm{O}_{2}$ consumption profiles (Figures $2 \mathrm{a}$ and $\mathrm{c}$ ). To achieve an equivalent rate of $\mathrm{O}_{2}$ consumption for rate comparison, 10 times more $N$. viennensis than N. multiformis cells were required in the $\mathrm{MR}$ chamber. Whereas N. multiformis showed a linear rate of $\mathrm{O}_{2}$ consumption during ammonia oxidation (Figure 2c), the initial rate of $\mathrm{O}_{2}$ consumption by $N$. viennensis was quite rapid, followed by a slower, linear rate (Figures 2a and b). N. viennensis produced a maximum of ca. $1.41 \mathrm{nM}$ of $\mathrm{NO}$ per $1 \times 10^{10}$ cells $(n=4)$ at the beginning of substrate oxidation, concomitant with the initial rapid rate of $\mathrm{O}_{2}$ consumption. The $\mathrm{NO}$ was immediately reconsumed as the cells achieved the slower, linear rate of $\mathrm{O}_{2}$ consumption (Figure 2a). After ca. $3 \mathrm{~min}$ from the point at which $\mathrm{O}_{2}$ became undetectable, $N$. viennensis cells began to release NO reaching a maximum of ca. $1.39 \mathrm{nM}$ per $1 \times 10^{10}$ cells $(n=4)$. None of the NO released by $N$. viennensis following $\mathrm{O}_{2}$ depletion was re-consumed. In contrast, N. multiformis produced a maximum of ca. $92.15 \mathrm{nM}$ NO per $1 \times 10^{10}$ cells $(n=4)$ and reconsumption of NO began once $c a$. $50 \%$ of the available $\mathrm{O}_{2}$ was consumed (Figure 2c).

Levels of $\mathrm{N}_{2} \mathrm{O}$ were measured during and following ammonia oxidation; however, no $\mathrm{N}_{2} \mathrm{O}$ was detectable during ammonia oxidation by cells of either microbe (Figures $2 \mathrm{~b}$ and $\mathrm{d}$ ). Assays including $N$. viennensis cells contained measurable $\mathrm{N}_{2} \mathrm{O}$ levels increasing at a non-linear rate after $c a$. $5 \mathrm{~min}$ following depletion of $\mathrm{O}_{2}$, yielding an average maximum at $c a .40 \mathrm{~min}$ of $0.19 \mu \mathrm{M}$ per $1 \times 10^{10}$ cells (Figure 2b; $n=4$ ). In contrast, assays including N. multiformis cells contained measurable $\mathrm{N}_{2} \mathrm{O}$ levels immediately upon $\mathrm{O}_{2}$ depletion increasing at a linear rate to an average maximum of $5.6 \mu \mathrm{M}$ per $1 \times 10^{10}$ cells at $c a .40$ min (Figure $2 \mathrm{~d} ; n=4$ ).

Dynamics of NO production and consumption during $\mathrm{NH}_{2} \mathrm{OH}$ oxidation by N. viennensis EN76 ${ }^{\mathrm{T}}$

Although the experiments described above indicated that $N$. viennensis cultures produce and consume NO during ammonia oxidation to nitrite, it was not clear whether NO acted as an intermediate in the ammonia- or hydroxylamine-oxidizing step of the pathway. Therefore, we examined production and consumption of NO by $N$. viennensis cells when fed with $\mathrm{NH}_{2} \mathrm{OH}$ instead of ammonium. $\mathrm{NH}_{2} \mathrm{OH}$ was added in $200 \mu \mathrm{M}$ pulses to the MR chamber containing $N$. viennensis cells to support linear $\mathrm{O}_{2}$ consumption until all of the available $\mathrm{O}_{2}$ was 
consumed (Figure 3). Each subsequent addition of equal aliquots of $\mathrm{NH}_{2} \mathrm{OH}$ led to the production of $c a$. $5 \mathrm{nM}$ NO per $1 \times 10^{10}$ cells $(n=3)$, followed by an immediate re-consumption of $\mathrm{NO}$ and $\mathrm{O}_{2}$ until the next addition of $\mathrm{NH}_{2} \mathrm{OH}$ (Figure 3 ). $\mathrm{NO}_{2}^{-}$accumulated to $c a .206 \mu \mathrm{M}(n=3)$ in the culture medium, which matched the $c a .207 \mu \mathrm{M} \mathrm{O}_{2}$ consumed during the time course of the experiment. Importantly, free conversion of $\mathrm{NH}_{2} \mathrm{OH}$ to $\mathrm{NO}$ in the absence of cells was stochastic and insignificant (Supplementary Figure S3a). Addition of $\mathrm{NH}_{2} \mathrm{OH}$ to FWM containing $200 \mu \mathrm{M} \mathrm{NaNO}$ resulted in the production of $c a .4 \mathrm{nM} \mathrm{NO}$ but only once a concentration of $1.2 \mathrm{mM} \mathrm{NH}_{2} \mathrm{OH}$ was reached in the MR chamber (Supplementary Figure S3b).

In an effort to demonstrate the requirement of NO by $N$. viennensis for the oxidation of either $\mathrm{NH}_{3}$ or $\mathrm{NH}_{2} \mathrm{OH}$, washed $N$. viennensis cells were incubated with $200 \mu \mathrm{M}$ PTIO for $1 \mathrm{~h}$ prior to measurement of $\mathrm{NH}_{4}^{+}$- or $\mathrm{NH}_{2} \mathrm{OH}$-dependent $\mathrm{O}_{2}$ consumption. The presence of PTIO did not prevent substratedependent $\mathrm{O}_{2}$ consumption of either substrate by $N$. viennensis cells (Supplementary Figure S1), although PTIO was able to effectively scavenge NO in cell-free FWM containing the NO-donating compound, PAPA-NONOate (Supplementary Figure S2).

\section{Detection of abiotic $\mathrm{N}_{2} \mathrm{O}$ in growth media without viable} cells

Inspired by the observed differences in $\mathrm{N}_{2} \mathrm{O}$ production profiles between cultures of $N$. viennensis and $N$. multiformis, we performed abiotic experiments in the MR chamber using cell-free FWM or HKM and the NO-donating compound, MAHMA NONOate. Addition of MAHMA NONOate to FWM released $c a$. $5.5 \mu \mathrm{M}$ NO, $70 \%$ of which was converted to $\mathrm{N}_{2} \mathrm{O}$ (Figure 4a). In contrast, addition of an equal aliquot of MAHMA NONOate to HKM resulted in only a $20 \%$ conversion of the released NO to $\mathrm{N}_{2} \mathrm{O}$ (Figure 4c). Continuous addition of MAHMA NONOate to produce $1.1-5.5 \mu \mathrm{M}$ NO in FWM or HKM resulted in a sustained high-efficiency conversion of released $\mathrm{NO}$ to $\mathrm{N}_{2} \mathrm{O}$ only in FWM, but not

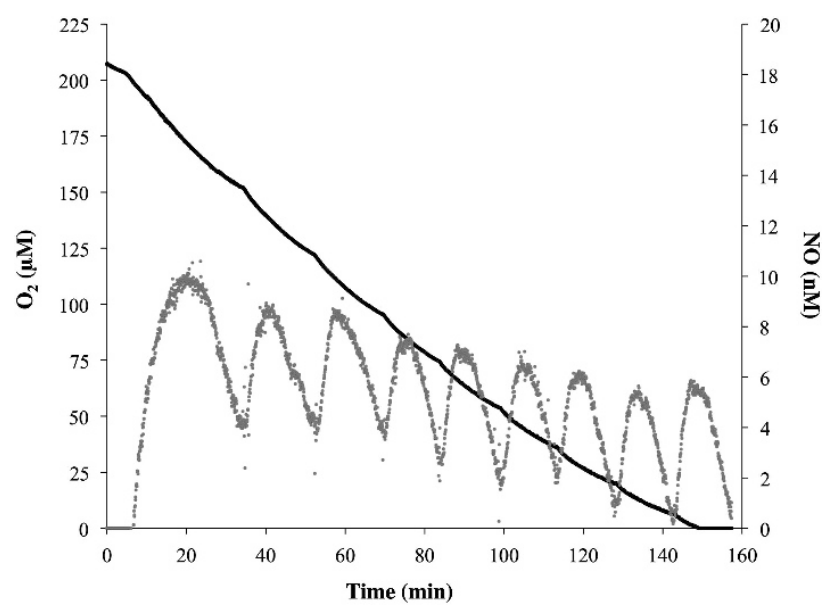

Figure 3 Instantaneous measurements of $\mathrm{O}_{2}$ consumption (black line) and NO production (grey dots) from $200 \mu \mathrm{M}$ pulses of $\mathrm{NH}_{2} \mathrm{OH}$ in liquid phase incubations of $N$. viennensis in the absence of $\mathrm{NH}_{4}^{+}$. Plot is a single representative of replicable experiments $(n=4)$.

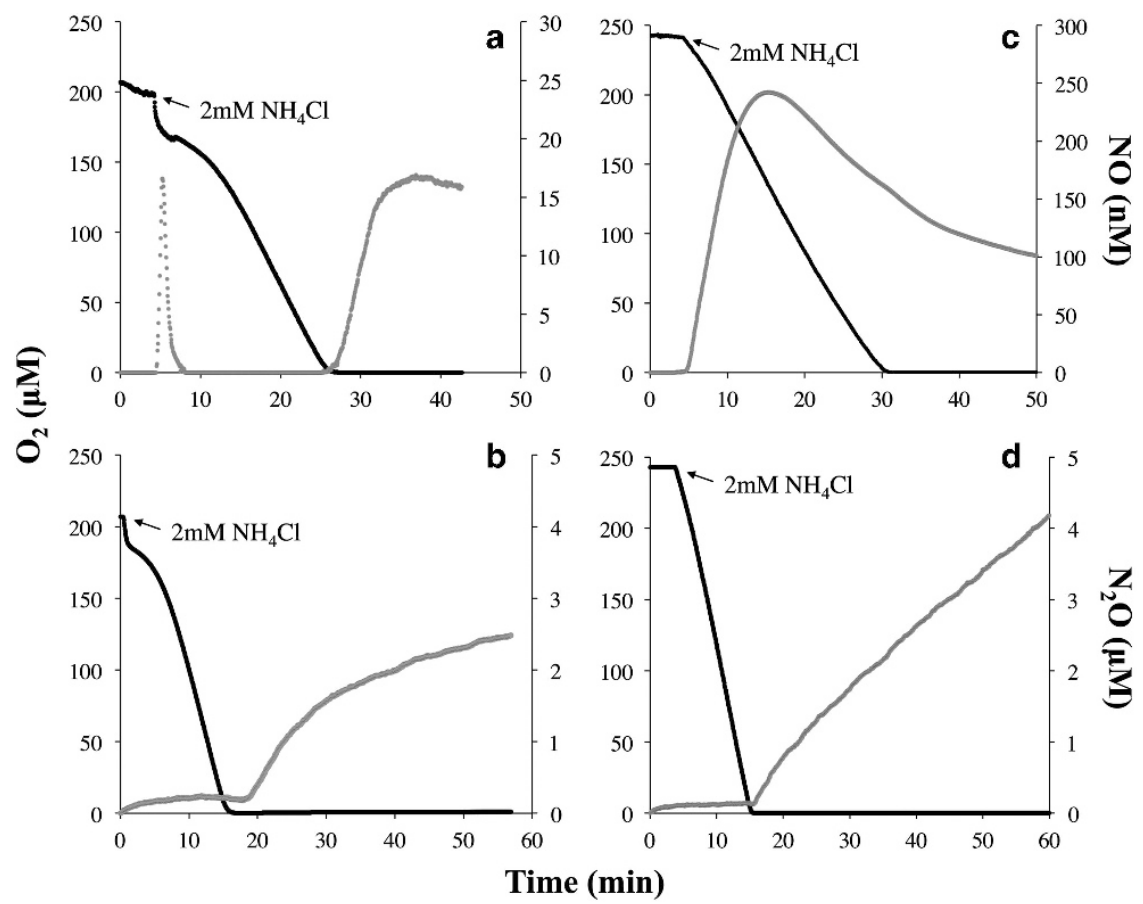

Figure 2 Instantaneous measurements of $\mathrm{O}_{2}$ (black line), $\mathrm{NO}$ (a and $\mathbf{c}$ ) and $\mathrm{N}_{2} \mathrm{O}$ (b and $\mathbf{d}$ ) (gray dots) after addition of 2 mM $\mathrm{NH}_{4} \mathrm{Cl}$ in liquid phase suspensions of $N$. viennensis (a and $\mathbf{b}$ ) and N. multiformis (c and $\mathbf{d}$ ) cells. Panels are single representative measurements of reproducible results $(n=4)$. Note that y-axes for $\mathrm{NO}$ are on different scales for $N$. viennensis versus $N$. multiformis. N. viennensis cell concentration was $10^{11}$ cells per ml, whereas $N$. multiformis cell concentration was $10^{10}$ cells per ml to achieve equivalent rates of $\mathrm{O}_{2}$ consumption by the two strains. 

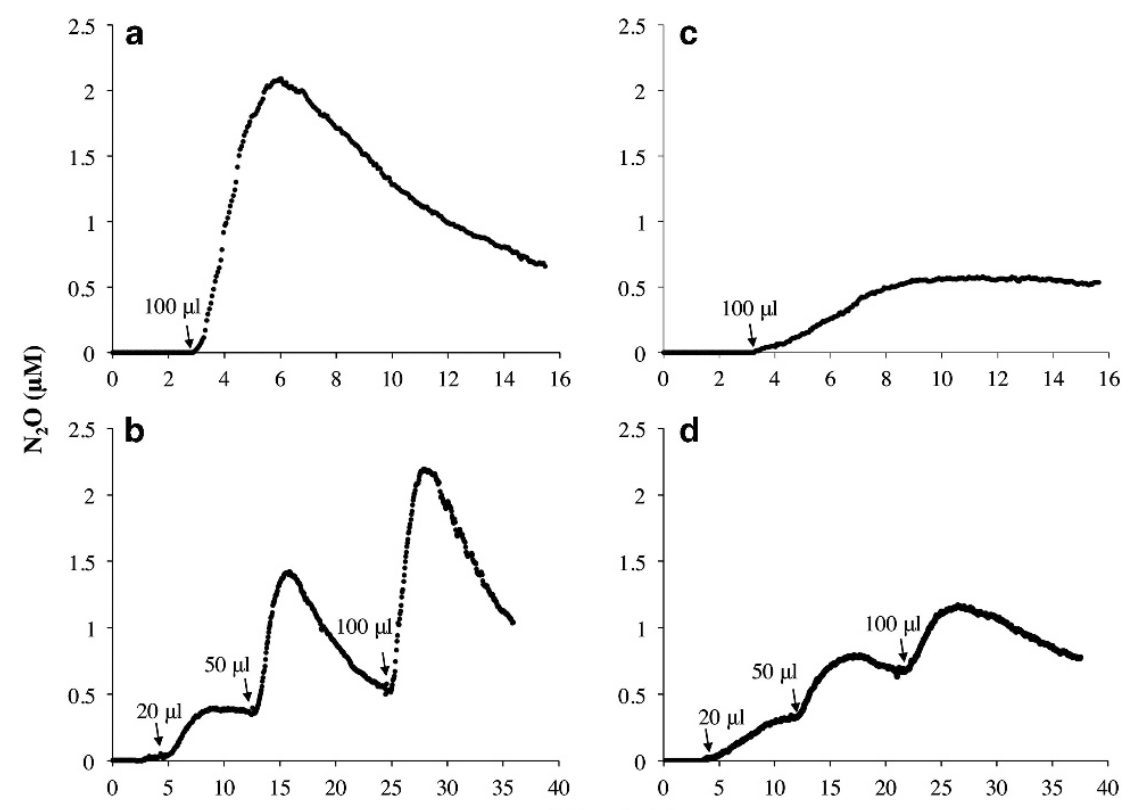

Figure 4 Abiotic production of $\mathrm{N}_{2} \mathrm{O}$ from the NO-donor MAHMA NONOate in either FWM (a and b) or HKM (c and d). Panels are single representative measurements of reproducible results $(n=3)$. The addition of varying concentrations of MAHMA NONOate is indicated by arrows.

HKM (Figures 4b and d). Reactivity of $\mathrm{NH}_{2} \mathrm{OH}$ in FWM+heat-killed $N$. viennensis cells was also explored (Supplementary Figure S4). When $\mathrm{NH}_{2} \mathrm{OH}$ was introduced into the MR chamber containing heat-killed cells, accumulation of NO reached ca. $110 \mathrm{nM}$ NO over 5 min (Supplementary Figure S4a). After $30 \mathrm{~min}, \mathrm{~N}_{2} \mathrm{O}$ accumulated to levels of $\mathrm{ca}$. $90 \mu \mathrm{M}$, demonstrating that $\mathrm{NH}_{2} \mathrm{OH}$ was eventually converted to $\mathrm{N}_{2} \mathrm{O}$ in the absence of physiologically active cells (Supplementary Figure S4b).

\section{Discussion}

The NO-scavenger, PTIO, stops ammonia-dependent chemolithotrophy of $\mathrm{N}$. viennensis

The measured cessation of ammonium consumption and nitrite production upon PTIO addition to growing cultures of $N$. viennensis demonstrates the requirement of free NO for ammonia chemolithotrophy that was not observed for $N$. multiformis. These results confirm prior growth experiments with enrichment cultures (Jung et al., 2014) and reported effects on nitrite production and activity by ammonia-oxidizing Thaumarchaea and bacteria incubated with PTIO (Shen et al., 2013; MartensHabbena et al., 2015). For both $N$. viennensis and $N$. multiformis, PTIO addition abolished $\mathrm{N}_{2} \mathrm{O}$ production, suggesting that the presence of the enzyme-generated free NO intermediate is required for formation of $\mathrm{N}_{2} \mathrm{O}$ production by both strains, regardless of whether NO is reduced biotically by enzyme activity or abiotically.
NO is produced and immediately consumed during active ammonia oxidation by N. viennensis $E N 76^{\mathrm{T}}$ The initial, rapid production of NO followed by its equally rapid consumption during ammonia-dependent $\mathrm{O}_{2}$ consumption by $N$. viennensis differed from results in similar experiments with $N$. maritimus SCM1 (Martens-Habbena et al., 2015). In this prior study, $N$. maritimus SCM1 produced NO at a steady-state level prior to its consumption once $\mathrm{NH}_{4}^{+}$was depleted or its partial consumption at saturating concentrations of $\mathrm{NH}_{4}^{+}$. A major difference in the two profiles observed for both cultures was that $\mathrm{O}_{2}$ levels remained quite high in assays with $N$. maritimus SCM1 such that complete consumption of NO was not observed as a function of time and $\mathrm{O}_{2}$ consumption as observed for $N$. viennensis $\mathrm{EN} 6^{\mathrm{T}}$. Even so, experiments with both $N$. viennensis and $N$. maritimus confirm that NO is being produced and consumed during ammonia oxidation. In addition, the present experiments demonstrate that NO is being released at the onset of anoxia. A likely fate of released $\mathrm{NO}$ at anoxia was its conversion to $\mathrm{N}_{2} \mathrm{O}$, because 1000 times more $\mathrm{N}_{2} \mathrm{O}$ than $\mathrm{NO}$ was measured once the microrespirometry chamber reached anoxia, suggesting rapid conversion of released $\mathrm{NO}$ to $\mathrm{N}_{2} \mathrm{O}$ (Figures 2a and c). Another contributor to $\mathrm{N}_{2} \mathrm{O}$ levels measured in anoxic assays with $N$. viennensis cells could be the reactivity of cell components with released $\mathrm{NH}_{2} \mathrm{OH}$ as heat-killed cells showed a rapid conversion of exogenous $\mathrm{NH}_{2} \mathrm{OH}$ to measureable $\mathrm{NO}$ and $\mathrm{N}_{2} \mathrm{O}$ (Supplementary figure S4).

NO dynamics during ammonium-dependent $\mathrm{O}_{2}$ consumption by $N$. multiformis showed a vastly different profile compared to that of either $N$. viennensis 
or N. maritimus, revealing ca. 10 times more NO released from the cells, some of which was slowly re-consumed during ammonia oxidation and through anoxia. The comparison of NOx profiles in microrespirometry measurements with cells of $N$. multiformis and the ammonia-oxidizing Thaumarchaea reveals an intriguing difference in how NOx is metabolized during ammonia oxidation by bacteria and Thaumarchaea, which requires further investigation. Unlike $N$. viennensis, $\mathrm{N}_{2} \mathrm{O}$ production by N. multiformis during anoxia was linear and 10 times more $\mathrm{N}_{2} \mathrm{O}$ was produced per number of cells. This is a confirmatory evidence that ammoniaoxidizing bacteria, but not $N$. viennensis, are capable of producing $\mathrm{N}_{2} \mathrm{O}$ enzymatically via nitrifier denitrification (Stieglmeier et al., 2014b).

\section{$\mathrm{NO}$ is produced and consumed during $\mathrm{NH}_{2} \mathrm{OH}$} oxidation to $\mathrm{NO}_{2}^{-}$in $\mathrm{N}$. viennensis

The rapid production and consumption of $\mathrm{NO}$ during $\mathrm{NH}_{2} \mathrm{OH}$ oxidation by $N$. viennensis along with the stoichiometric production of $\mathrm{NO}_{2}^{-}$with $\mathrm{O}_{2}$ consumption suggest that $\mathrm{NO}$ is directly participating in the dehydrogenation of $\mathrm{NH}_{2} \mathrm{OH}$. Recent models have postulated that $\mathrm{NO}$ is involved in providing reductant to ammonia monooxygenase (Schleper and Nicol, 2010; Stahl and de la Torre, 2012); however, if this were the case then the rapid production/consumption cycle of $\mathrm{NO}$ during $\mathrm{NH}_{2} \mathrm{OH}$ oxidation would not be observed. Experiments to demonstrate the role of $\mathrm{NO}$ in $\mathrm{NH}_{2} \mathrm{OH}$ oxidation by pre-incubating washed cells with PTIO with the goal to observe quenching of $\mathrm{NH}_{3}$ or $\mathrm{NH}_{2} \mathrm{OH}$-dependent $\mathrm{O}_{2}$ consumption were inconclusive. It is possible that PTIO is only effective during active growth of $N$. viennensis (which was observed; Figure 1), or perhaps PTIO was ineffective at chelating rapidly cycling $\mathrm{NO}$ at the high cell densities used in the MR chamber.

$\mathrm{N}_{2} \mathrm{O}$ in $\mathrm{N}$. viennensis cultures originates from the abiotic reaction of biotic $N$-oxide intermediates with medium or cellular components

Previous studies measuring $\mathrm{N}_{2} \mathrm{O}$ in pure and enrichments cultures of ammonia-oxidizing Thaumarchaea suggested an enzymatic origin of measured $\mathrm{N}_{2} \mathrm{O}$ (Santoro et al., 2011; Loscher et al., 2012; Jung et al., 2014); however, control experiments to test for abiotic reduction of $\mathrm{NO}$ to $\mathrm{N}_{2} \mathrm{O}$, including by medium components, were not performed. We observed a high rate of $\mathrm{NO}$ reduction to $\mathrm{N}_{2} \mathrm{O}$ in FWM both in the presence of an $\mathrm{NO}$-donating molecule and in the presence of $\mathrm{NH}_{2} \mathrm{OH}$ plus heat-killed cells. Based on the difference in metal content of both media, we propose that reduction of $\mathrm{NO}$ to $\mathrm{N}_{2} \mathrm{O}$ in FWM is facilitated by iron, which is present in FWM at a relatively high final concentration of $7.5 \mathrm{uMl}^{-1}$ in the form of FeNaEDTA but absent from HKM. Under anoxic conditions, in which the metal components of the medium are reduced, the Fe(II) and reduced trace metals act as chemical catalysts for NO reduction to $\mathrm{N}_{2} \mathrm{O}$. This 'chemodenitrification' process has been implicated by hypothesis in contributing to abiotic $\mathrm{N}_{2} \mathrm{O}$ production in reduced environments where $\mathrm{Fe}(\mathrm{II})$ is abundant (Samarkin et al., 2010; Kampschreur et al., 2011; Jones et al., 2015).

Proposed pathway for ammonia chemolithotrophy in ammonia-oxidizing Thaumarchaea in which NO facilitates $\mathrm{NH}_{2} \mathrm{OH}$ oxidation

Our revised model of ammonia-dependent chemolithotrophy of the Thaumarchaeota places $\mathrm{NO}$ as a necessary co-reactant for the oxidation of $\mathrm{NH}_{2} \mathrm{OH}$ to $\mathrm{NO}_{2}^{-}$(Figure 5a). This NO-dependent dehydrogenation of $\mathrm{NH}_{2} \mathrm{OH}$ to $\mathrm{NO}_{2}^{-}$is not based on novel chemistry because ammonia-oxidizing bacteria, and others such as aerobic methane-oxidizing bacteria, utilize the heme-containing cytochrome P460 enzyme to facilitate this reaction (Figure 5b; Simon and Klotz, 2013). Instead, the central reaction in the Thaumarchaeotal nitrification pathway is based on a proposed novel copper enzyme capable of performing known P460 activity. This model achieves the proper substrate stoichiometry and reductant flow. In addition, the modelled rapid cycling of $\mathrm{NO}$ (and, concomitantly electrons) to support $\mathrm{NH}_{2} \mathrm{OH}$ oxidation would logically preclude any enzymology for $\mathrm{NO}$ reduction to $\mathrm{N}_{2} \mathrm{O}$. In agreement with this requirement, none of the sequenced genomes of ammonia-oxidizing Thaumarchaeota revealed the presence of canonical and alternate inventory for $\mathrm{NO}$ reduction to $\mathrm{N}_{2} \mathrm{O}$. Nitrite reductase (nirK) is encoded in the genomes of all published sequences of ammonia-oxidizing Thaumarchaea (Bartossek et al., 2010, 2012) and nirK transcripts have been detected at very high steady-state levels in environmental metatranscriptomes (Hollibaugh et al., 2011; Radax et al., 2012), which makes this enzyme the most parsimonious source of the NO needed to support ammonia-dependent chemolithotrophy. The proposal that $\mathrm{NO}_{2}^{-}$reduction and not $\mathrm{NH}_{2} \mathrm{OH}$ oxidation is the more likely source of the $\mathrm{NO}$ required for the oxidation of $\mathrm{NH}_{2} \mathrm{OH}$ to $\mathrm{NO}_{2}^{-}$ is supported by the following logic and reasoning:

(1) A two-step oxidation of $\mathrm{NH}_{2} \mathrm{OH}$ to $\mathrm{NO}_{2}^{-}$via a $\mathrm{NO}$ intermediate would require the operation of two enzyme complexes that feed extracted electrons $(3+1)$ via two redox shuttles to two quinone-reactive enzymes. In addition to requiring additional unknown inventory, such a pathway would also not generate enough electrons needed to provide for effective linear electron flow $(4-2-1=1)$. In contrast, the proposed one-step model provides for effective linear electron flow (5-2-1=2; Figure 5). The bioenergetics contrast stands in the context that an observed active NirK activity would draw one electron per reduced $\mathrm{NO}_{2}^{-}$in both scenarios in addition to that the two-step model would include two linearly connected sources of NO production in a genomic background not encoding identifiable NO detoxification inventory and a scenario 
a
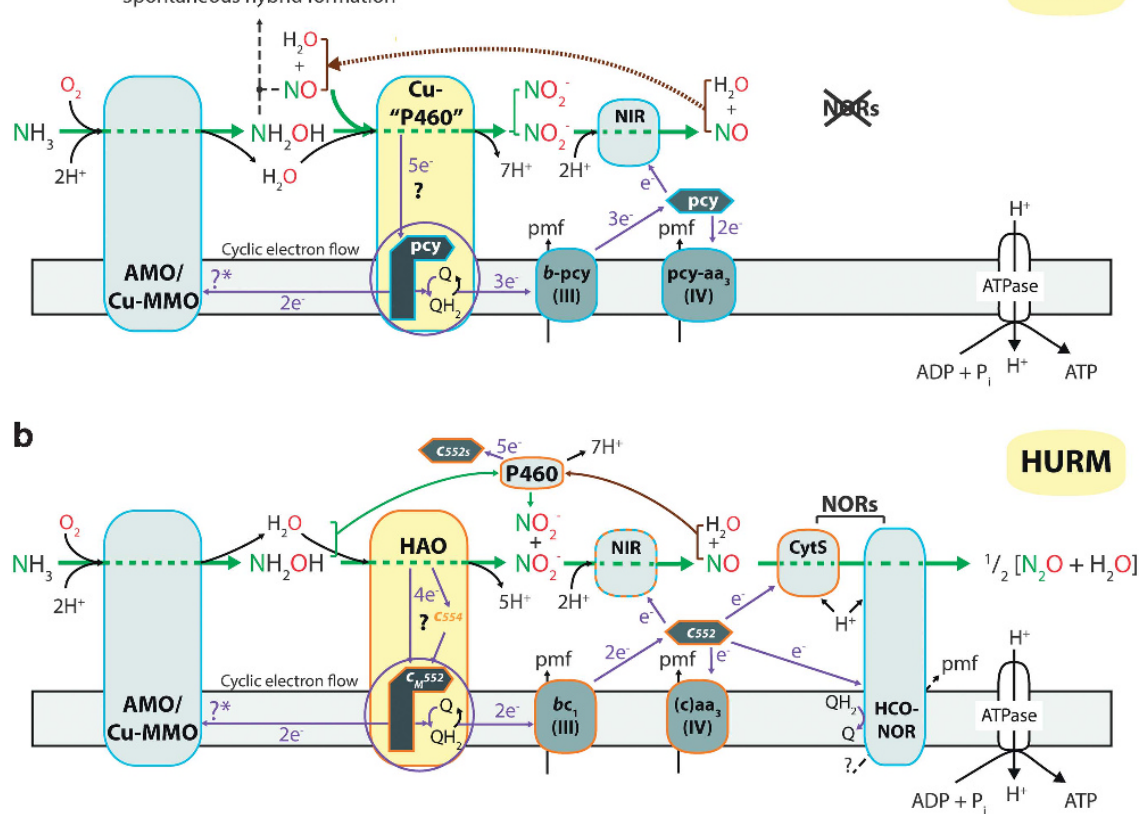

Figure 5 Proposed pathway for ammonia-dependent chemolithotrophy in the ammonia-oxidizing Thaumarchaea (a) compared with known pathways of N-oxide transformation in ammonia-oxidizing bacteria (b). The model presents a central role of NO in the oxidation of $\mathrm{NH}_{2} \mathrm{OH}$, and its contribution to hybrid formation of $\mathrm{N}_{2} \mathrm{O}$ as proposed by Stieglmeier et al. (2014b). Due to the lack of heme proteins including $\mathrm{HAO}$ and quinone-reactive proteins such as $\mathrm{C}_{\mathrm{M}} 552$ (CycB), redox processes in ammonia-oxidizing archaea are likely mediated by $\mathrm{Cu}$ protein complexes (Walker et al., 2010; Stahl and de la Torre, 2012). The present literature suggests that $\mathrm{NH}_{3}$ is monooxygenated to $\mathrm{NH}_{2} \mathrm{OH}$ by ammonia monooxygenase (AMO) and that $\mathrm{NH}_{2} \mathrm{OH}$ is dehydrogenated to $\mathrm{NO}_{2}^{-}$by activities of a number of unknown enzymes (Walker et al., 2010; Stahl and de la Torre, 2012; Vajrala et al., 2012). Based on existing chemistry facilitated by heme proteins in ammonia-oxidizing bacteria (b), the model in (a) proposes that the oxidation of $\mathrm{NH}_{2} \mathrm{OH}$ to $\mathrm{NO}_{2}^{-}$and subsequent extraction of five electrons results from a reaction of $\mathrm{NH}_{2} \mathrm{OH}$ with $\mathrm{NO}$ and $\mathrm{H}_{2} \mathrm{O}$ facilitated by a novel Cu-containing enzyme. This could be one of the multi-copper oxidases encoded in all genomes of ammonia-oxidizing Thaumarchaeota (Bartossek et al., 2010, 2012; Walker et al., 2010). NO is provided by the $\mathrm{Cu}$-containing NirK, which enzymatically reduces one $\mathrm{NO}_{2}^{-}$per $\mathrm{NH}_{3}$ oxidized to $\mathrm{NO}$. A fraction of the enzyme-produced $\mathrm{NO}$ and $\mathrm{NH}_{2} \mathrm{OH}$ could react to form $\mathrm{N}_{2} \mathrm{O}$ by hybrid formation. The figure was adapted from Simon and Klotz (2013). AMO/Cu-MMO, ammonia monooxygenase; $c 552$, cytochrome $c$ redox carrier; CytS: cytochrome $c$ '-beta (see Simon and Klotz, 2013, and references therein); HAO, hydroxylamine dehydrogenase; HCO, heme-copper oxidase; HURM, hydroxylamine:ubiquinone redox module (see Simon and Klotz, 2013, and references therein); NirK, Cu-containing NO-forming nitrite reductase; NOR, nitric oxide reductase; P460, tetraheme cytochrome $c$ protein P460 (CytL; see Simon and Klotz, 2013, and references therein); pcy, plastocyanin; pmf, proton-motive force; Q/QH ${ }_{2}$, quinone/ quinol pool.

that should not lead to stoichiometric conversion of $\mathrm{N}-\mathrm{NH}_{3}$ to $\mathrm{N}-\mathrm{NO}_{2}^{-}$.

(2) Isotopic measurements of ${ }^{15} \mathrm{~N}_{2} \mathrm{O}$ produced by $N$. viennensis suggest a 'hybrid signature' in that one $\mathrm{N}$ atom would originate from $\mathrm{NH}_{3}$ (contributed as $\mathrm{NH}_{2} \mathrm{OH}$ ) and one atom would originate from $\mathrm{NO}_{2}^{-}$ (contributed as NO) (Stieglmeier et al., 2014b). This finding also contradicts a two-step model and supports the model shown in Figure 5.

The proposed one-step model is parsimonious in that it requires the innovation of only one enzyme in ammonia-oxidizing Thaumarchaea. Based on existing knowledge, this novel enzyme is copper-based and facilitates known redox chemistry in context with known enzyme complexes such as the $\mathrm{NH}_{2} \mathrm{OH}$ producing ammonia monooxygenase, NO-producing NirK, plastocyanin redox carriers and a quinonereactive membrane protein, all of which are copper proteins and have been identified in all sequenced genomes of ammonia-oxidizing Thaumarchaea (Walker et al., 2010; Bartossek et al., 2012; Stahl and de la Torre, 2012).
We propose that the model of catabolic electron flow presented here (Figure 5a) applies to all obligate chemolithotrophic ammonia-oxidizing Thaumarchaea because it is based on and supported by results from above referenced experiments with marine ammoniaoxidizing Thaumarchaea including $N$. maritimus SCM1 and experiments with terrestrial ammoniaoxidizing Thaumarchaeota including the data presented here for $N$. viennensis EN76 ${ }^{\mathrm{T}}$.

\section{Conclusion}

The present study establishes that both ammoniaoxidizing Thaumarchaea and bacteria contribute to the production of $\mathrm{N}_{2} \mathrm{O}$, although the mechanisms by which they do so are distinct. Whereas the ammonia-oxidizing bacteria produce $\mathrm{N}_{2} \mathrm{O}$ enzymatically through nitrifier denitrification, the ammoniaoxidizing Thaumarchaea release intermediates (NO and/or $\mathrm{NH}_{2} \mathrm{OH}$ ), which are then reduced nonenzymatically to $\mathrm{N}_{2} \mathrm{O}$ in anoxic microenvironments 
(Zhu-Barker et al., 2015). Due to the relatively high abundance and activity of Thaumarchaea across terrestrial, freshwater, and marine environments (Zhang et al., 2010; Pratscher et al., 2011; French et al., 2012; Berg et al., 2015) and their established tolerance of low ammonium and oxygen environments (Martens-Habbena et al., 2009), their contributions to NOx emissions is likely of high global significance (Babbin et al., 2015). For instance, marine Thaumarchaea may be essential in providing a substantial concentration of NO to denitrifying microorganisms within oxygen minimum zones, and in return, the denitrifiers could provide organic carbon to the Thaumarchaeota to establish a nitrifyingdenitrifying consortium (Karner et al., 2001; Beman et al., 2012; Ganesh et al., 2015). The present study also supports that both ammonia-oxidizing Thaumarchaea and bacterial ammonia-oxidizers likely contribute to chemodenitrification in terrestrial environments through the release and subsequent transformation of metabolites $\left(\mathrm{NH}_{2} \mathrm{OH}\right.$, $\mathrm{NO}$ and $\left.\mathrm{NO}_{2}^{-}\right)$either abiotically or via denitrifying consortia (Jones et al., 2015), which dominate in less oligotrophic environments. The elucidation of $\mathrm{NO}$ as an essential pathway intermediate and released metabolite of the ammoniaoxidizing Thaumarchaea in the absence of a nitrifier denitrificaiton pathway will allow refinement of the relative contributions of ammonia-oxidizing microorganisms to global $\mathrm{N}_{2} \mathrm{O}$ production.

\section{Conflict of Interest}

The authors declare no conflict of interest.

\section{Acknowledgements}

JK was supported by graduate fellowship funds from Alberta Innovates Technology Futures. LYS was supported by a discovery grant from NSERC (RGPIN-2014-03745). Work in CS laboratory was supported by the Austrian Science Fund grant P25369. MGK was supported by NSF grant MCD1202648.

\section{References}

Arp DJ, Chain P, Klotz MG. (2007). The impact of genome analyses on our understanding of ammonia-oxidizing bacteria. Annu Rev Microbiol. 61: 503-528.

Babbin AR, Bianchi D, Jayakumar A, Ward BB. (2015). Nitrogen cycling. Rapid nitrous oxide cycling in the suboxic ocean. Science 348: 1127-1129.

Bartossek R, Nicol GW, Lanzen A, Klenk HP, Schleper C. (2010). Homologues of nitrite reductases in ammoniaoxidizing archaea: diversity and genomic context. Environ Microbiol 12: 1075-1088.

Bartossek R, Spang A, Weidler G, Lanzen A, Schleper C. (2012). Metagenomic analysis of ammonia-oxidizing archaea affiliated with the soil group. Front Microbiol 3: 208.

Beman JM, Popp BN, Alford SE. (2012). Quantification of ammonia oxidation rates and ammonia-oxidizing archaea and bacteria at high resolution in the Gulf of California and eastern tropical North Pacific Ocean. Limnol Oceanogr 57: 711-726.

Berg C, Vandieken V, Thamdrup B, Jürgens K. (2015). Significance of archaeal nitrification in hypoxic waters of the Baltic Sea. ISME J 9: 1319-1332.

Clesceri LS, Greenberg AE, Eaton AD. (1998). Standard Methods for the Examination of Water and Wastewater. 20th edn, American Public Health Assoc: Washington, DC, USA.

French E, Kozlowski JA, Mukherjee M, Bullerjahn G, Bollmann A. (2012). Ecophysiological characterization of ammonia-oxidizing archaea and bacteria from freshwater. Appl Environ Microbiol 78: 5773-5780.

Ganesh S, Bristow LA, Larsen M, Sarode N, Thamdrup B, Stewart FJ. (2015). Size-fraction partitioning of community gene transcription and nitrogen metabolism in a marine oxygen minimum zone. ISME J 9: 2682-2696.

Goldstein S, Russo A, Samuni A. (2003). Reactions of PTIO and carboxy-PTIO with NO, NO2, and $\mathrm{O}_{2}^{-}$. J Biol Chem 278: 50949-50955.

Hollibaugh JT, Gifford S, Sharma S, Bano N, Moran MA. (2011). Metatranscriptomic analysis of ammoniaoxidizing organisms in an estuarine bacterioplankton assemblage. ISME J 5: 866-878.

Jones LC, Peters B, Pacheco JSL, Casciotti KL, Fendorf S. (2015). Stable isotopes and iron oxide mineral products as markers of chemodenitrification. Environ Sci Technol 49: 3444-3452.

Jung MY, Well R, Min D, Giesemann A, Park SJ, Kim JG et al. (2014). Isotopic signatures of $\mathrm{N}_{2} \mathrm{O}$ produced by ammonia-oxidizing archaea from soils. ISME J 8: 1115-1125.

Kampschreur MJ, Kleerebezem R, de Vet WWJM, van Loosdrecht MCM. (2011). Reduced iron induced nitric oxide and nitrous oxide emission. Water Res 45 : 5945-5952.

Karner MB, DeLong EF, Karl DM. (2001). Archaeal dominance in the mesopelagic zone of the Pacific Ocean. Nature 409: 507-510.

Kim BK, Jung M-Y, Yu DS, Park S-J, Oh TK, Rhee S-K et al. (2011). Genome sequence of an ammonia-oxidizing soil archaeon, 'Candidatus Nitrosoarchaeum koreensis' MY1. J Bacteriol 193: 5539-5540.

Könneke M, Schubert DM, Brown PC, Hügler M, Standfest S, Schwander T et al. (2014). Ammonia-oxidizing archaea use the most energy-efficient aerobic pathway for CO2 fixation. Proc Natl Acad Sci 111: 8239-8244.

Krümmel A, Harms H. (1982). Effect of organic matter on growth and cell yield of ammonia-oxidizing bacteria. Arch Microbiol 133: 50-54.

Loscher CR, Kock A, Konneke M, LaRoche J, Bange HW, Schmitz RA. (2012). Production of oceanic nitrous oxide by ammonia-oxidizing archaea. Biogeosciences 9: $2419-2429$.

Martens-Habbena W, Berube PM, Urakawa H, de la Torre JR, Stahl DA. (2009). Ammonia oxidation kinetics determine niche separation of nitrifying Archaea and Bacteria. Nature 461: 976-979.

Martens-Habbena W, Qin W, Horak REA, Urakawa H, Schauer AJ, Moffett JW et al. (2015). The production of nitric oxide by marine ammonia-oxidizing archaea and inhibition of archaeal ammonia oxidation by a nitric oxide scavenger. Environ Microbiol. 17: 2261-2274.

Pratscher J, Dumont MG, Conrad R. (2011). Ammonia oxidation coupled to CO2 fixation by archaea and 
bacteria in an agricultural soil. Proc Natl Acad Sci 108: 4170-4175.

Radax R, Rattei T, Lanzen A, Bayer C, Rapp HT, Urich T, Schleper C. (2012). Metatranscriptomics of the marine sponge Geodia barretti: tackling phylogeny and function of its microbial community. Environ Microbiol 14: 1308-1324.

Samarkin VA, Madigan MT, Bowles MW, Casciotti KL, Priscu JC, McKay CP et al. (2010). Abiotic nitrous oxide emission from the hypersaline Don Juan Pond in Antarctica. Nature Geosci 3: 341-344.

Santoro AE, Buchwald C, McIlvin MR, Casciotti KL. (2011). Isotopic signature of $\mathrm{N}_{2} \mathrm{O}$ produced by marine ammonia-oxidizing archaea. Science 333: 1282-1285.

Sayavedra-Soto L, Arp DJ. (2011). Ammonia-oxidizing bacteria: their biochemistry and molecular biology. In: Ward BB, Arp DJ, Klotz MG (eds), Nitrification. ASM Press: Washington, DC, USA, pp 11-37.

Schleper C, Nicol GW. (2010). Ammonia-oxidising archaea- physiology, ecology and evolution. Adv Microb Physiol 57: 1-41.

Shen T, Stieglmeier M, Dai J, Urich T, Schleper C. (2013). Responses of the terrestrial ammonia-oxidizing archaeon Ca. Nitrososphaera viennensis and the ammonia-oxidizing bacterium Nitrosospira multiformis to nitrificiation inhibitors. FEMS Microbiol Lett 344: 121-129.

Simon J, Klotz MG. (2013). Diversity and evolution of bioenergetic systems involved in microbial nitrogen compound transformations. Biochim Biophys Acta 1827: 114-135.

Skinner FA, Walker N. (1961). Growth of Nitrosomonas europaea in batch and continuous culture. Arch Microbiol 38: 339-349.

Spang A, Poehlein A, Offre P, Zumbrägel S, Haider S, Rychlik N et al. (2012). The genome of the ammoniaoxidizing Candidatus Nitrososphaera gargensis: insights into metabolic versatility and environmental adaptations. Environ Microbiol 14: 3122-3145.

Stahl DA, de la Torre JR. (2012). Physiology and diversity of ammonia-oxidizing archaea. Annu Rev Microbiol 66: 83-101.

Stieglmeier M, Klingl A, Alves RJE, Rittmann SK-MR, Melcher M, Leisch N et al. (2014a). Nitrososphaera viennensis gen. nov., sp. nov., an aerobic and mesophilic, ammonia-oxidizing archaeon from soil and a member of the archaeal phylum Thaumarchaeota. Int J Syst Evol Microbiol 64: 2738-2752.

Stieglmeier M, Mooshammer M, Kitzler B, Wanek W, Zechmeister-Boltenstern S, Richter A et al. (2014b). Aerobic nitrous oxide production through N-nitrosating hybrid formation in ammonia-oxidizing archaea. ISME J 8: 1135-1146.

Tourna M, Stieglmeier M, Spang A, Konneke M, Schintlmeister A, Urich $\mathrm{T}$ et al. (2011). Nitrososphaera viennensis, an ammonia oxidizing archaeon from soil. Proc Natl Acad Sci 108: 8420-8425.

Vajrala N, Martens-Habbena W, Sayavedra-Soto LA, Schauer A, Bottomley PJ, Stahl DA et al. (2012). Hydroxylamine as an intermediate in ammonia oxidation by globally abundant marine archaea. Proc Natl Acad Sci 110: 1006-1011.

Walker CB, de la Torre JR, Klotz MG, Urakawa H, Pinel N, Arp DJ et al. (2010). Nitrosopumilus maritimus genome reveals unique mechanisms for nitrification and autotrophy in globally distributed marine crenarchaea. Proc Natl Acad Sci 107: 8818-8823.

Zhang L-M, Offre PR, He J-Z, Verhamme DT, Nicol GW, Prosser JI. (2010). Autotrophic ammonia oxidation by soil thaumarchaea. Proc Natl Acad Sci 107: 17240-17245.

Zhu-Barker X, Cavazos AR, Ostrom NE, Horwath WR, Glass JB. (2015). The importance of abiotic reactions for nitrous oxide production. Biogeochemistry 126: 251-267.

Supplementary Information accompanies this paper on The ISME Journal website (http://www.nature.com/ismej) 